\title{
Objective knowledge about Huntington's disease and attitudes towards predictive tests of persons at risk*
}

\author{
BETTY TELTSCHER † AND STEPHEN POLGAR \\ From $\dagger$ the Department of Psychiatry, University of Melbourne; and $\ddagger$ the Department of \\ Behavioural Sciences, Lincoln Institute, Melbourne, Australia
}

SUMMARY The task of genetic counselling of people at risk for Huntington's disease might be facilitated by increased knowledge of relevant population characteristics. The aim of the present study was to clarify select socioeconomic characteristics, knowledge concerning the disease, and attitudes towards predictive tests of people at $50 \%$ risk of inheriting Huntington's disease in the state of Victoria.

A random sample of subjects was drawn from the Huntington's disease register and 50 questionnaires were analysed. Respondents completed three questionnaires which covered their socioeconomic characteristics, the extent and accuracy of their knowledge about the genetics, progress, and treatment of Huntington's disease, and their attitude and acceptance of predictive tests as well as their intentions about future reproduction.

A very positive attitude was found to be held by the respondents towards a predictive test if it was safe, reliable, and non-invasive. Resultant problems which would arise, should a reliable test be found, are discussed. The respondent's knowledge concerning the disease was found to be adequate generally.

Huntington's disease (HD) is an autosomal dominant disorder, involving the gradual degeneration of specific regions of the nervous system. One of the aims of genetic counselling is to provide factual information concerning the nature of the condition for subjects suffering from or at risk for HD.

The task of the genetic counsellor may be facilitated by factual information concerning the general socioeconomic characteristics of the population with which he is working. The aim of the present study was to increase systematic knowledge concerning selected characteristics of those people in Victoria, Australia who have a $50 \%$ chance of inheriting HD. The socioeconomic characteristics of our population, such as education, occupation, marital status, and number of children, has not been previously studied and it was thought that knowledge of such variables could be useful in analysing socially relevant issues.

The level of knowledge of this population concerning the genetics, progress, and treatment of HD is also of interest in determining the effectiveness of genetic counselling programmes previously carried *Substance of paper presented at the first Australian Huntington's
Disease Conference at Balwyn in November 1979.

Received for publication 21 March 1980 out, and in providing a baseline against which the effectiveness of future programmes for providing information might be measured. A point of particular interest was to discover if there were any specific areas of factual knowledge which people at risk of inheriting HD may commonly misunderstand or have trouble in applying to their own situations.

One of the most difficult tasks facing genetic counsellors is that HD does not generally manifest itself until early middle-age ${ }^{1}$ and there are no valid signs to judge if a person at risk carries the gene responsible for HD. A variety of techniques which may become predictive tests are being developed to detect the HD gene before the onset of the disease. Given a variety of possible psychological and social problems for people at risk with the future advent of a successful predictive test, it was thought relevant to investigate their attitudes towards such tests. That is, do people at risk want them and do they say that they will use them when available?

In a previous study in the USA, Stern and Eldridge $^{2}$ found that $77 \%$ of people at $50 \%$ risk reported that they were willing to undergo predictive testing. In a later study, Barette and Marsden $^{3}$ reported from the UK that $80 \%$ of respondents from families affected with HD said that they wished members 
of their families to undertake predictive tests. Unfortunately, in both studies the subjects contacted were selected from membership lists of lay organisations of HD families. Given that membership of these organisations is voluntary, the data came from non-representative samples. Further, the rate of questionnaire returns from the people contacted in the above studies was rather low and could reflect a systematic bias. For example, Stern and Eldridge ${ }^{2}$ sent out 2600 questionnaires, but received back less than 1065 , a less than $41 \%$ return rate. Of the respondents $71 \%$ were females indicating a strong possibility for sex determined bias in returning questionnaires, or membership of the lay organisation, or both.

In the present study, the availability of an up-todate register of Victorian Huntington's disease pedigrees $^{4}$ made it possible to obtain a representative sample of people at risk for study.

Correlations among the variables measured were determined, for while correlations need not unequivocally represent causal relationships it was thought they could be the source of hypotheses for future systematic studies of the population 'at risk' for HD.

\section{Methods}

In 1979 in the state of Victoria (population 3811500 ) there were 1200 subjects at $50 \%$ risk, 568 of whom were between 18 and 45 years of age. One hundred and thirty subjects at $50 \%$ risk of developing HD and who were between the ages of 18 and 45 were randomly selected from the HD pedigree files of the Huntington's Disease Clinic at the Psychiatry Department, Melbourne University. Questionnaires were sent to 73 of these 130 subjects. Of the original 130 subjects, 51 could not be contacted, 36 because their address was unknown and ten because they had moved interstate and it had been initially decided to limit the survey to people who lived in Victoria. Five subjects were regarded as unsuitable respondents to the questionnaire for psychiatric reasons or because of insufficient English. It was considered ethically unsuitable to contact six of the subjects, as the department had had no previous contact with them or their immediate families.

It was often necessary to contact a relative of the subject to legitimise the expected participation of the subject in the survey. In these cases it had to be determined that the subject knew that he was at risk so that he would not be presented with something of which he had no knowledge.

A covering letter was sent with the questionnaire which explained the project and expressed the importance that the investigators felt it had for future medical research.

The questionnaire was based on a pilot study by a group of physiotherapists studying at Lincoln Institute. Part I contained questions concerning socioeconomic characteristics and personal information. Part II contained 14 multiple choice questions, designed to test the subject's factual knowledge of HD. These questions were based on information from a pamphlet distributed by the Australian Huntington's Disease Association. Part III contained eight questions, each involving a 6 point scale ranging from very positive to very negative, to measure the subject's attitudes towards predictive tests. Two pairs of questions were symmetrical opposites. In order to deter the subjects from making noncommital decisions, the neutral category was omitted from the scale. Part IV contained items to determine the subject's attitudes towards treatment and research.

\section{Results}

QUESTIONNAIRE RETURNS

Seventy-three questionnaires were dispatched and 53 were completed and returned. Only 50 were used in the final analysis as two were returned after data analysis had started and one respondent was found to be above the age limit (45 years) that had been previously set. The overall return rate was $72 \cdot 6 \%$.

The social characteristics of the 50 respondents are shown in tables $1-5$.

TABLE 1 Sex and marital status

\begin{tabular}{lll}
\hline & Males & Females \\
\hline Sex & 23 & 27 \\
Married & 12 & 18 \\
Single & 10 & 7 \\
Widowed/divorced & 1 & 2 \\
\hline
\end{tabular}

\section{TABLE 2 Education}

\begin{tabular}{llr}
\hline Primary only & (6 years) & 1 \\
Some secondary & (up to 12 years) & 23 \\
Completed secondary (12 years, and some college) & 23 \\
Completed tertiary & (completed college) & 3 \\
\hline
\end{tabular}

TABLE 3 Occupational status

\begin{tabular}{lcc}
\hline Stutus & Males & Femules \\
\hline Blue collar & 12 & 3 \\
White collar & 4 & 6 \\
Professional & 5 & 2 \\
Home duties & 1 & 15 \\
Student & 1 & 1 \\
Unemployed & 1 & \\
\hline
\end{tabular}


TABLE 4 Children

\begin{tabular}{lrlll}
\hline & No & $\begin{array}{l}\text { Consider } \\
\text { future } \\
\text { children }\end{array}$ & $\begin{array}{l}\text { No intention } \\
\text { of having } \\
\text { children }\end{array}$ & Undecided \\
\hline $\begin{array}{l}\text { Married with 1 } \\
\text { or more } \\
\text { children* }\end{array}$ & 26 & 1 & 22 & 3 \\
$\begin{array}{l}\text { Married with no } \\
\text { children }\end{array}$ & 5 & 4 & 1 & 0 \\
$\begin{array}{l}\text { Single, no child } \\
\text { Divorced/ }\end{array}$ & 16 & 4 & 4 & 8 \\
\hline widowed & 3 & & & \\
\hline
\end{tabular}

*Married category includes 'de facto' status.

TABLE 5 Most significant source of information about $H D^{*}$

\begin{tabular}{lr}
\hline Friends and relatives & 27 \\
Specialist & 20 \\
Books and films & 11 \\
Family doctor & 5 \\
\hline
\end{tabular}

*Other sources included the Australian Huntington's Disease Association, social workers, and newspapers. Some respondents noted more than one source.

OBJECTIVE KNOWLEDGE OF HD

The respondents' level of objective knowledge, as measured by the present test, was quite high with a mean score of $11 \cdot 64$ out of a maximum of 14 . The distribution of the scores was markedly negatively skewed. Of the subjects, $41(82 \%)$ scored 10 or more correct answers. The lowest score was 5 . Ten subjects $(20 \%)$ answered all questions correctly.

The objective knowledge questionnaire (appendix) can be conveniently divided into three general areas: symptoms and progress of HD, mode of inheritance, and treatment (tables 6, 7, 8).

TABLE 6 Objective knowledge: symptoms and progress of disease*

\begin{tabular}{ll}
\hline Question & Correctly answered \\
\hline Most common physical changes & $100 \%$ \\
Progression of symptoms & $96 \%$ \\
Possibility of a person at risk but with no & $82 \%$ \\
symptoms transmitting condition & $74 \%$ \\
Most common onset age & $72 \%$ \\
Which part of the body is primarily affected & Possibility of a person showing symptoms of \\
$\quad$ HD before their parent & $68 \%$ \\
\hline
\end{tabular}

*See appendix for complete questionnaire.

TABLE 7 Objective knowledge: mode of inheritance of disease

\begin{tabular}{ll}
\hline Question & Correctly answered \\
\hline How is HD contracted & $98 \%$ \\
Does sex of parent influence inheritance & $86 \%$ \\
What are the chances of inheritance & $82 \%$ \\
Does sex of person at risk influence inheritance & $80 \%$ \\
Likely number to inherit HD in a 4 child family & $70 \%$ \\
\hline
\end{tabular}

TABLE 8 Objective knowledge: treatment of disease

\begin{tabular}{ll}
\hline Question & Correctly answered \\
\hline Common form of treatment & $88 \%$ \\
Effectiveness of current treatment & $88 \%$ \\
\hline
\end{tabular}

Subsequent analysis of the data indicated that the amount of knowledge about Huntington's disease did not correlate significantly with age, sex, educational level, or the source from which they obtained their knowledge.

It could not be said that one category of people had a better knowledge or understanding of the facts about this disease than another or that the high levels of knowledge were the result of general educational levels.

\section{ATTITUDES TOWARDS PREDICTIVE TESTS}

Following the method suggested by Likert (Anastasi $^{5}$ ) for analysing the answers, the eight attitude questions (see appendix) were ranked so that for each item a definitely negative attitude to predictive tests was counted as a score of one, with the scores increasing by one to a maximum of six, which showed a very positive attitude to predictive tests. While such numbers were not treated as of ratio or interval scales, a high total score for the eight items was thought to reflect a generally positive attitude towards predictive tests, while a low score was a negative attitude. The total score of 32 on the eight items was taken as the cut-off point, so that a respondent scoring a total of 32 or more was counted as having a generally positive attitude towards predictive tests.

Thirty-two (64\%) of respondents to the questionnaire were found to have a generally positive attitude and $18(36 \%)$ a generally negative attitude. Subsequent analyses of the data showed there were no significant correlations of attitudes with sex, age, marital status, level of education, number of children, or objective knowledge of HD.

Table 9 shows the specific conditions under which

TABLE 9 Positive attitudes towards predictive tests

\begin{tabular}{llc}
\hline & \multicolumn{2}{l}{$\begin{array}{l}\text { Respondents with } \\
\text { positive attitudes } \\
\text { No }\end{array}$} \\
& & \\
\hline Who should have tests? & 44 & 88 \\
People at risk considering children & 42 & 84 \\
All people at risk should be encouraged & 38 & 76 \\
Children of people at risk & & \\
Conditions of test & 42 & 84 \\
$100 \%$ sure, safe, and simple & 34 & 68 \\
Less than $100 \%$ sure, but safe and simple & 31 & 62 \\
$100 \%$ sure, but invasive and complicated & & \\
\hline
\end{tabular}


predictive tests were acceptable, that is, the number of respondents scoring 4 or more on each of the questions.

\section{Discussion}

The use of the HD register enabled the random selection of a sample of people at 50/50 risk between the ages of 18 and 45 . However, the people actually contacted in this study did not constitute an entirely representative sample, as those with known psychological problems or those who had not definitely been informed about their being 'at risk' were not included. Given the ethical problems involved in surveys such as these, it was clear that to prevent possible psychological trauma the subject selection could not be strictly random.

The socioeconomic characteristics of the sample did not appear strikingly different from the rest of the Victorian population. As far as family planning is concerned, none of the people who had two or more children expressed a desire to have any more. Of the 21 married respondents who had no children, seven were anticipating having children, six were not, and eight were undecided. Once again, the data have not been analysed to decide if these trends deviated significantly from the rest of the population. It seems reasonably clear, however, that married 'at risk' people with children seem to be content with maintaining the Australian national average. The present findings do not support the notion of a high level of reproduction among people at risk in Victoria.

It was gratifying to find a high level of knowledge concerning the essential facts of HD. It is clear that only a relatively small percentage of people at risk are ignorant about the condition. Further, there were no specific areas of knowledge about HD concerning which the group were seriously misinformed. However, it is interesting to note that while $82 \%$ knew that the risk involv. $d$ in gene transmission was $50 \%$ (table 7) only $70 \%$ could use this information for predicting the probable number of children with HD in a family. This finding is of interest, in that it shows that some people at risk should be given specific information about applying genetic knowledge.

It is interesting to note that in contrast with the subjects at risk, when the fifth year medical students were given the objective questionnaire, they appeared to be confused about the personality changes in HD, its common age of onset, and the fact that HD genes are autosomal. Given the small sample, it is not possible to draw definite conclusions about the implications of this finding, but it could represent common misconceptions in the medical community concerning HD.
Overall, people at risk were found to have a positive attitude towards predictive tests. However, when the individual items in the attitude scale are considered, the condition under which people want these tests emerges (table 9). In particular, most respondents $(88 \%)$ thought that people at risk considering having children should have tests. As expected, the $100 \%$ sure, safe, and simple test was seen as most desirable. That $84 \%$ of subjects were found to have positive attitudes towards such a test was consistent with previous findings by Stern and Eldridge, ${ }^{2}$ who found that $77 \%$ of their $50 \%$ risk respondents wanted predictive tests, and those of Barette and Marsden ${ }^{3}$ who found that $80 \%$ of their sample were willing to have their family members undergo predictive tests. It is clear from the close correspondence of these findings from different English speaking countries that the majority of people at risk for HD report to be willing to participate in predictive testing. While these findings may encourage those scientists working to develop predictive tests, the clinicians who will eventually apply them feel the need to debate the possible guidelines for "handling the results before the test is introduced". 6

Social workers, who are often responsible for the ongoing supportive contact with families and subjects in what is often a chronic problem, will be faced with a crisis situation for their clients and their families.

Some of the issues which will need to be debated are: How old should children be before they are allowed to take a predictive test and how old before they are told the result? What safeguards can there be to ensure the confidentiality of such a test and what rights will superannuation funds or potential employers have to require 'at risk' persons to undergo such tests?

The attitudes of not only those affected by Huntington's disease, but of many others in society will be important.

This work was supported by a grant from the National Health and Medical Research Council. In addition, we wish to thank Ms Libby Saunders for N organising the survey, Mr Graeme Hyman for computing and analysing the data, and the respondents $\tilde{O}$ who co-operated with us in our survey. The pilot $N_{\omega}^{N}$ study for the present project was carried out by J Chisholm, S Labberton, L Smith, J Stevens, and 0 $\mathrm{V}$ Townsend.

\section{References}

1 Bruyn GW. Huntington's chorea. Historical, clinical and $\frac{\rho}{\Phi}$ laboratory synopsis. In: Vinken PJ, Bruyn GW, eds. @ 
Handbook of clinical neurology. vol. 6. Amsterdam: North-Holland, 1968:298-378.

2 Stern R, Eldridge R. Attitudes of patients and their relatives to Huntington's disease. J Med Genet 1975;12: 217-23.

3 Barette J, Marsden CD. Attitudes of families to some aspects of Huntington's chorea. Psychol Med 1979;9: 327-36.

4 Chiu E, Teltscher B. Huntington's disease. The establishment of a National Register. Med J Aust 1978;2:394-6.
5 Anastasi A. Psychological testing. 3rd ed. London: Macmillan, 1970:486-7.

- Editorial. Predictive tests in Huntington's chorea. $\mathrm{Br}$ Med $J$ 1978 ;i:528-9.

Requests for reprints to Mrs Betty Teltscher, Department of Psychiatry, Clinical Sciences Building, Royal Melbourne Hospital, Melbourne, Victoria 3050, Australia. 
APPENDIX

Questionnaire concerning Huntington's disease

Please complete the following

Sex: $\square$ Male $\square$ Female $\quad$ Date of birth:

Marital status: $\square$ Single $\quad \square$ Divorced

$\square$ Married $\square$ Widowed

$\square$ Other (please specify)

Number of years married

Occupation

Level of education attained:

$\square$ Primary

Some secondary

Completed secondary

Some tertiary

Completed tertiary

Number of children, if any, and year of birth:

No children

\begin{tabular}{|l|l|l|l|l|l|l|}
\hline Child & 1 & 2 & 3 & 4 & 5 & 6 \\
\hline $\begin{array}{l}\text { Date } \\
\text { of birth }\end{array}$ & & & & & & \\
\hline
\end{tabular}

Do you intend to have any/more children?

$\square$ Yes $\quad \square$ No $\quad \square$ Undecided

If yes, how many?

Do you suffer from any serious or long term medical conditions, for example, arthritis, diabetes, heart disease?

At what age did you find out that you were at risk of developing Huntington's disease (HD)?

Which of your relatives had or are presently suffering from HD?

From which source did you gain most of your knowledge of HD?

Family doctor

Specialist

Friends or relatives

Books or films

Other (Please specify) 


\section{Objective questionnaire}

The aim of this questionnaire is to test your knowledge concerning Huntington's disease (HD). For each question tick the item that you think is correct. Answer all questions even if you have to make a guess.

(1) Which part of the body is primarily damaged in Huntington's disease (HD)?

$\square$ Muscles and tendons

$\square$ The brain

The nerves in the limbs

The heart and arteries

(2) How is HD contracted?
$\square$ Virus infection
Heredity
Close contact with a carrier
Alcoholism or drug abuse

(3) What is the most common age group for the onset of symptoms of $\mathrm{HD}$ ?

$\square 24$ or less
$\square 25-34$
$\square 35-44$
$\square 45$ or more

(4) What are the most common personality changes in HD?

The onset of unusual and irrational fears

Compulsive eating and drinking

Delusions and hallucinations

Irritability and extremes of mood

(5) What are the most common physical changes in HD?

Jerky movements and twitching

Gradual paralysis of limbs

Painful, swollen joints

Rigidity and tremor

(6) Once the symptoms of HD appear they become

$\square$ Progressively worse

$\square$ Progressively better

$\square$ Stay the same indefinitely

Progressively worse, then better

(7) What are the chances that a parent with HD will pass the condition to his children?
$\square 25 \%$ chance
$\square 50 \%$ chance
$\square 75 \%$ chance
$100 \%$ chance

(8) What form of treatment is common for HD?

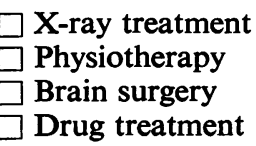

(9) In what way is the current means of treatment effective?

Not effective at all

Partial control of symptoms

Arrest of progress of disease

Complete cure of disease

(10) Is it possible for a person at risk who hasn't yet shown the symptoms of HD to transmit the condition to his/her children?

$\square$ It is possible

$\square$ It is not possible

Yes, if the parent was physically unfit

Yes, if the parent is a male

(11) Can a person with HD show symptoms of the condition before his/her parent?

Only rarely

No

Only if the mother was under stress during pregnancy

$\square$ Only if the person was under stress during infancy

(12) Does the sex (male or female) of the parent with HD influence the chance of the children inheriting HD?

Yes, it has an influence

No, it has no influence

It rarely has an influence

It frequently has an influence.

(13) How does the sex of the person influence his/ her likelihood of developing HD?

$\square$ Males are more likely than females to develop HD

$\square$ Females are more likely than males to develop HD

$\square$ Males and females are equally likely to develop HD

$\square$ Don't know

(14) In a family with 4 children where one of the parents has HD how many of the children are likely to have HD?

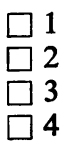


Attitude towards predictive tests

Tests for detecting the presence of the gene responsible for HD in people at risk (predictive tests) are now being developed by scientists. This work is still in its formative stages. However, we would like to know your feelings towards such predictive tests. Please indicate how you feel towards the following questions by marking the appropriate box.

(1) Do you believe that all people at risk should be encouraged to have such a test?

$\begin{array}{cccccc}\begin{array}{c}\text { Definitely } \\ \text { yes }\end{array} & \begin{array}{c}\text { Probably } \\ \text { yes }\end{array} & \begin{array}{c}\text { Unsure, but } \\ \text { possibly } \\ \text { yes }\end{array} & \begin{array}{c}\text { Unsure, but } \\ \text { possibly } \\ \text { no }\end{array} & \begin{array}{c}\text { Probably } \\ \text { no }\end{array} & \begin{array}{c}\text { Definitely } \\ \text { no }\end{array} \\ & & & & & \end{array}$

(2) Do you believe that all people at risk and considering having children should have such a test done? $\stackrel{\oplus}{\dot{\omega}}$

$\begin{array}{cccccc}\begin{array}{c}\text { Definitely } \\ \text { yes }\end{array} & \begin{array}{c}\text { Probably } \\ \text { yes }\end{array} & \begin{array}{c}\text { Unsure, but } \\ \text { possibly } \\ \text { yes }\end{array} & \begin{array}{c}\text { Unsure, but } \\ \text { possibly } \\ \text { no }\end{array} & \begin{array}{c}\text { Probably } \\ \text { no }\end{array} & \begin{array}{c}\text { Definitely } \\ \text { no }\end{array} \\ & & & \text { no } & & \end{array}$

(3) Would you be willing to have a child of yours undertake a predictive test?

$\begin{array}{ccccc}\begin{array}{c}\text { Definitely } \\ \text { yes }\end{array} & \begin{array}{c}\text { Probably } \\ \text { yes }\end{array} & \begin{array}{c}\text { Unsure, but } \\ \text { possibly } \\ \text { yes }\end{array} & \begin{array}{c}\text { Unsure, but } \\ \text { possibly } \\ \text { no }\end{array} & \begin{array}{c}\text { Probably } \\ \text { no }\end{array} \\ & & \text { yes } & \text { no }\end{array}$

$\square$
Definitely
no

(4) Would you discourage a child of yours from having such a test?

$\begin{array}{cccccc}\begin{array}{c}\text { Definitely } \\ \text { yes }\end{array} & \begin{array}{c}\text { Probably } \\ \text { yes }\end{array} & \begin{array}{c}\text { Unsure, but } \\ \text { possibly } \\ \text { yes }\end{array} & \begin{array}{c}\text { Unsure, but } \\ \text { possibly } \\ \text { no }\end{array} & \begin{array}{c}\text { Probably } \\ \text { no }\end{array} & \begin{array}{c}\text { Definitely } \\ \text { no }\end{array} \\ & & \text { yes } & & \end{array}$

(5) If a predictive test was less than $100 \%$ certain in detecting the presence of HD genes, but was safe and simple, would you still have it done?

\begin{tabular}{|c|c|c|c|c|c|}
\hline $\begin{array}{c}\text { Definitely } \\
\text { yes }\end{array}$ & $\begin{array}{c}\text { Probably } \\
\text { yes }\end{array}$ & $\begin{array}{l}\text { Unsure, but } \\
\text { possibly } \\
\text { yes }\end{array}$ & $\begin{array}{l}\text { Unsure, but } \\
\text { possibly } \\
\text { no }\end{array}$ & $\begin{array}{c}\text { Probably } \\
\text { no }\end{array}$ & $\begin{array}{c}\text { Definitely } \\
\text { no }\end{array}$ \\
\hline
\end{tabular}

(6) If such a test was $100 \%$ certain, but involved painful procedures and/or admittance to hospital for a period of time, would you have it done?

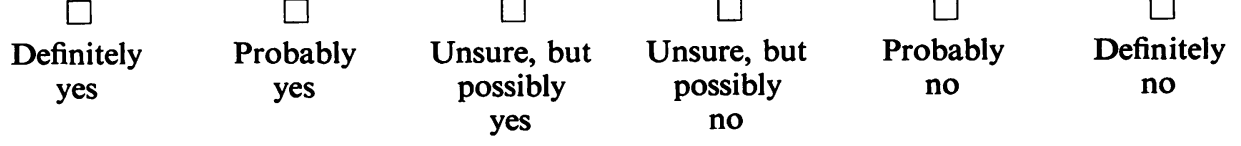

(7) If such a test was safe, simple, and $100 \%$ certain in detecting HD would you have it done?

$\begin{array}{cccccc}\begin{array}{c}\text { Definitely } \\ \text { yes }\end{array} & \begin{array}{c}\text { Probably } \\ \text { yes }\end{array} & \begin{array}{c}\text { Unsure, but } \\ \text { possibly } \\ \text { yes }\end{array} & \begin{array}{c}\text { Unsure, but } \\ \text { possibly } \\ \text { no }\end{array} & \begin{array}{c}\text { Probably } \\ \text { no }\end{array} & \begin{array}{c}\text { Definitely } \\ \text { no }\end{array} \\ & & & & & \end{array}$


(8) Would you avoid having a predictive test if it was safe and simple, but less than $100 \%$ certain in predicting the onset of HD?

$\begin{array}{cccccc}\begin{array}{c}\text { Definitely } \\ \text { yes }\end{array} & \begin{array}{c}\text { Probably } \\ \text { yes }\end{array} & \begin{array}{c}\text { Unsure, but } \\ \text { possibly } \\ \text { yes }\end{array} & \begin{array}{c}\text { Unsure, but } \\ \text { possibly } \\ \text { no }\end{array} & \begin{array}{c}\text { Probably } \\ \text { no }\end{array} & \begin{array}{c}\text { Definitely } \\ \text { no }\end{array} \\ & & & & \end{array}$

(9) What, in your opinion are the most important research projects?

Please rank 1-3

Research into the treatment of the physical symptoms of HD

Research into tests to predict who will develop HD

Research into the treatment of the personality symptoms of HD

Do you think research into other areas might also be important?

Yes

No

If yes, please state what area.

(10) Do you think it will be better for HD patients if they are cared for in a home specifically designed for Huntington's disease sufferers?

$\begin{array}{cccccc}\begin{array}{c}\text { Definitely } \\ \text { yes }\end{array} & \begin{array}{c}\text { Probably } \\ \text { yes }\end{array} & \begin{array}{c}\text { Unsure, but } \\ \text { possibly } \\ \text { yes }\end{array} & \begin{array}{c}\text { Unsure, but } \\ \text { possibly } \\ \text { no }\end{array} & \begin{array}{c}\text { Probably } \\ \text { no }\end{array} & \begin{array}{c}\text { Definitely } \\ \text { no }\end{array} \\ & & & & & \end{array}$

(11) Can you foresee any problems for yourself or your family if you have a relative living in a home which is known to be for Huntington's disease patients?

$\begin{array}{cccccc}\begin{array}{c}\text { Definitely } \\ \text { yes }\end{array} & \begin{array}{c}\text { Probably } \\ \text { yes }\end{array} & \begin{array}{c}\text { Unsure, but } \\ \text { possibly } \\ \text { yes }\end{array} & \begin{array}{c}\text { Unsure, but } \\ \text { possibly } \\ \text { no }\end{array} & \begin{array}{c}\text { Probably } \\ \text { no }\end{array} & \begin{array}{c}\text { Definitely } \\ \text { no }\end{array} \\ & & & & & \end{array}$

(12) If you foresee problems, could you please say what these problems might be. 